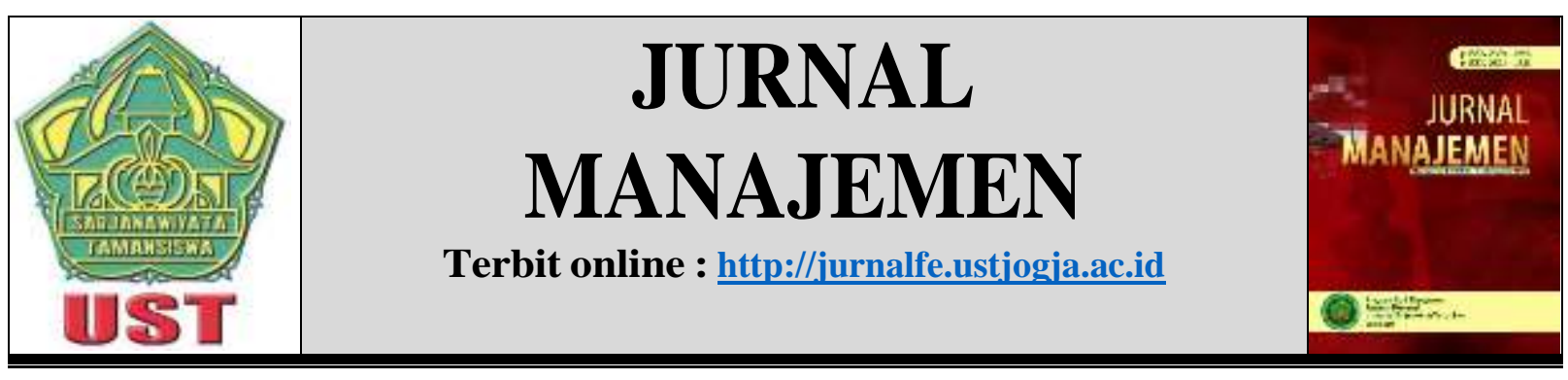

PERTUMBUHAN KARTU KREDIT DI INDONESIA DALAM PANDEMI COVID'19

\title{
Meki Dudiyanto
}

Prodi Manajemen, Fakultas Ekonomi, President University

E-mail: mekydudiyanto@gmail.com

\begin{tabular}{ll}
\hline Informasi Naskah & \multicolumn{1}{c}{ Abstrak } \\
\hline Diterima: & AKKI (Association of Indonesian Credit Card Issuers) is an \\
04 November 2020 & organization that aims to build a healthy credit card industry and is \\
Revisi: & responsible for credit card Issuers, Cardholders, Merchants, Principals \\
07 Desember 2020 & (American Express, JCB International, MasterCard International and \\
Terbit: & Visa International) and other parties other related. AKKI in \\
18 Juni 2021 & collaboration with its members also builds a sound and safe credit card \\
\hline Kata Kunci: & industry infrastructure. AKKI currently has 24 members of credit card \\
Pertumbuhan Kartu & issuing institutions with a total number of card holders of more than 17 \\
Kredit, Pandemi, AKKI & million (based on April 2019 data) who collaborate with more than 450 \\
& thousand merchants, AKKI is a forum to support completeness in doing \\
& credit card business in Indonesia. \\
& The survey was conducted for obtain early information regarding \\
& banking policies in lending, funding and determination of interest rates, \\
& developments in credit demand and supply new. \\
& Together with all elements of the Criminal Justice System (CJS) such as \\
& the Republican Police, AKKI is trying to improve security in conducting \\
& credit card transactions for cardholders and merchants. Convenience \\
& and security in conducting credit card transactions are the basic \\
& objectives of AKKI in building the credit card industry in Indonesia. \\
\hline
\end{tabular}

\section{PENDAHULUAN}

Kartu kredit di Indonesia pertama kali diperkenalkan sekitar tahun 1980-an oleh Bank Duta yang bekerja sama dengan prinsipal VISA dan MasterCard Internasional. Bank Dutalah yang menjadi bank pertama di Indonesia yang memasarkan atau menerbitkan kartu kredit. Kartu kredit tersebut ditujukan kepada nasabah-nasabah mereka sendiri. Tidak ditujukan kepada semua orang seperti saat ini. Waktu itu kartu kredit yang dipasarkan hanya untuk mengincar orang-orang kaya, pengusaha, pejabat atau orang-orang kelas tertentu yang sering melancong ke luar negeri. Daripada membawa uang tunai yang banyak dan berat, tentu saja membawa sebuah kartu jauh lebih baik, lebih aman dan lebih nyaman. Uang dalam bentuk cek perjalanan (traveler's cheque) atau giro sekalipun memiliki kendala yang sama yakni bisa rusak, sobek, hilang dicuri dan dipergunakan orang lain. Tidak demikian dengan kartu kredit. 
Perlu diketahui bahwa Bank Duta untuk saat ini sudah tinggal nama. Ini menjadi bukti bahwa menjadi yang pertama tidaklah selalu menjadi yang terbaik dan bertahan selamanya. Beberapa tahun kemudian masuklah pemain-pemain baru di industri kartu kredit seperti BCA, Citibank, Hongkong Bank, dst. Pertama kali datang, Citibank belum merubah logo dan namanya. Waktu itu namanya kalau tidak salah masih City Bank. Nama yang menggambarkan sebuah bank di kota besar yang sangat padat penduduknya.

Citibank sangat fokus pada produk kartu kredit sehingga membuatnya meraih banyak keuntungan dan begitu terkenal hingga ke seluruh penjuru dunia. Pada awal era tahun 1990-an semua orang jika memiliki kartu kredit Citibank, bangganya bukan main. Namun sayangnya proses persetujuannya tidaklah segampang saat ini (tahun 2000 ke atas). Maklum karena pelaku pasar waktu itu masih sedikit jumlahnya. HSBC waktu itu masih bernama Hongkong Bank. Pada waktu kami masih menjadi salah satu sales marketing kartu kredit Citibank, ada pameo yang berbunyi dan ini benar adanya.

Sistem Kartu Kredit adalah suatu jenis penyelesaian transaksi ritel (retail) dan sistem kredit yang diterbitkan kepada pengguna sistem tersebut (Wikipedia, 2020). Kartu kredit adalah salah satu instrumen utang yang dikeluarkan oleh pihak bank. Kartu kredit menjadi hal yang sangat berguna untuk mereka yang mengerti cara pemakaiannya tapi akan berdampak negatif jika pegang kartu kredit tidak mengetahui aturan main dari kartu kredit. Sebuah kartu kredit berbeda dengan kartu debit di mana penerbit kartu kredit meminjamkan konsumen uang dan bukan mengambil uang dari rekening. Kebanyakan kartu kredit memiliki bentuk dan ukuran yang sama, seperti yang dispesifikasikan oleh standar ISO 7810.

Kartu kredit adalah salah satu dari beberapa instrumen utang yang dikeluarkan oleh bank. Kehadiran kartu kredit sendiri sering menjadi pisau bermata dua, yaitu menjadi hal yang sangat berguna bagi mereka yang mengerti aturan main dari kartu kredit itu sendiri dan di sisi lain seolah menjadi bumerang bagi mereka yang tidak mengerti aturan main dari kartu kredit.

Contoh nyatanya adalah guyonan bahwa kartu kredit adalah kartu setan. Entah ini sekadar guyonan atau persepsi yang salah dari masyarakat kita yang sudah ada sejak lama, tetap menjadi pandangan dan pengalaman dari masing-masing orang itu sendiri.

Namun bagi mereka yang suka atau tidak yang telah memakai kartu kredit dan merasakan dampak positif dan negatifnya, atau mereka yang belum pernah menggunakannya sama sekali, ada baiknya mengetahui aturan main yang ada di dalam kartu kredit. Aturan main dalam kartu kredit yang sering dipandang sebelah mata oleh setiap orang yang memakainya atau pun yang menghindarinya yaitu adalah jenis-jenis biaya yang terdapat di dalam kartu kredit. Kenapa kita harus mengetahui ini? Mudahnya menghindari kerugian atau jeratan utang yang menumpuk sehingga kita bisa menggunakan kartu kredit dengan bijak dan maksimal, bukannya jadi mempersulit dan memberatkan.

\section{KAJIAN PUSTAKA DAN HIPOTESIS Jenis Kartu Kredit}

Kartu Kredit merupakan bentuk pembiayaan untuk transaksi pembelian barang dan jasa dengan memakai Kartu, yang akan ditagihkan kemudian kepada Pengguna oleh Penerbit Kartu Kredit. Jenis Kartu kredit juga terdiri dari yaitu :

- Bank Credit Card, merupakan kartu kredit yang diterbitkan oleh bank pemegang franchise Card Company untuk kalangan nasabahnya sendiri;

- Co-Branded Card, merupakan kartu kredit yang diterbitkan untuk keuntungan badan usaha tertentu;

- Affinity Card, merupakan kartu kredit yang diterbitkan untuk kepentingan organisasi non-profit. 


\section{Menurut Bank Indonesia Syarat Memiliki Kartu Kredit :}

1. Pemegang kartu kredit minimal berumur 21 tahun atau telah menikah. Pemegang kartu kredit tambahan berumur minimal 17 tahun.

2. Pendapatan per bulan minimum dari pemegang kartu kredit adalah Rp3 juta.

3. Pengaturan jumlah kartu kredit dan plafon kredit bagi pemegang kartu dengan penghasilan antara Rp3 juta - Rp10 juta antara lain:

a) Jumlah maksimal penerbit kartu kartu kredit yang boleh memberikan fasilitas kartu kredit kepada satu pemegang kartu adalah 2 (dua) penerbit kartu.

b) Jumlah total plafon kredit yang diberikan oleh semua penerbit kartu kredit kepada 1 pemegang kartu kredit adalah 3 (tiga) kali penghasilan bulanan (dibuktikan dengan slip gaji, faktur pajak, dan pembuktian lainnya).

c) Tidak ada pengaturan khusus untuk pemegang kartu dengan penghasilan di atas Rp10 juta per bulan. Pengaturan tersebut dikembalikan kepada penerbit kartu untuk disesuaikan dengan risk appetite masing-masing.

\section{Manfaat Kartu Kredit}

Manfaat kartu kredit antara lain Dapat mengatasi pembayaran kebutuhan dana yang mendesak tanpa harus mengajukan permohonan ke Bank, Lebih praktis karena tidak perlu membawa uang tunai dalam jumlah banyak, keamanan terjamin karena kartu dapat diblokir oleh penerbit kartu kredit, dapat menikmati fasilitas dari merchant seperti diskon pembayaran, kemudahan pembelian barang dan jasa serta informasi kesehatan.

\section{Perjanjian Kartu Kredit}

\section{a) Perjanjian Antara Issuer Dan Acquirer}

Isi perjanjian kartu kredit dengan pemilik kartu antara lain adalah masa berlaku kartu dan perpanjangan, hak pemblokiran kartu, bunga atas tagihan yang belum dibayar, bunga atas pelanggaran limit kredit, biaya uang pangkal, biaya iuran tahunan, biaya administrasi, mekanisme khilangan kartu, jaminan pelunasan dari kekayaan pemilik kartu (Budisantosa \& Nuritomo, 2017).

b) Perjanjian Antara Issuer Dan Merchant

Isi perjanjian kartu kredit antara lain adalah Jaminan bahwa penjualan dengan kartu tidak lebih besar dari penjualan tunai, Diskon pembayaran issuer oleh merchant, pemotongan rekening merchant oleh pajak, pemotongan rekening merchant untuk refund kepada pemilik kartu. Kewajiban meminta tandatangan keabsahan pemilik kartu kredit, kewajiban memberikan slip penjualan kepada pemilik kartu, jangka waktu penagihan dan cara pembayaran kepada penerbit kartu kredit (Budisantosa \& Nuritomo, 2017).

\section{Transaksi ATM dan Kartu Kredit Turun 18,9 Persen Selama Pandemi}

Penggunaan transaksi dengan kartu ATM dan kartu kredit di masa pandemi mengalami penurunan. Gubernur Bank Indonesia, Perry Warjiyo mengatakan transaksi kartu debit dan kartu kredit mengalami penurunan sebesar 18,9 persen. Sementara itu, berbagai pelayanan bank melalui sistem digital mengalami peningkatan. Transaksi transfer, simpanan dan lainnya maik 37,8 persen. Penggunaan uang elektronik juga ikut naik hingga 65 persen.

Pandemi Covid-19 membuat sebagian orang membatasi pengeluaran mereka. Hal ini dikarenakan pendapatan yang masuk juga berkurang, sehingga untuk menjaga keuangan, mereka memilih tidak membeli beberapa barang yang biasanya selalu mereka beli. Namun, untuk beberapa orang dengan pengeluaran yang sulit dibatasi, kartu kredit jadi salah satu penolong. Bukan untuk hal konsumtif, melainkan sebagai penyeimbang arus kas. 
Direktur Konsumer Bank Rakyat Indonesia (BRI) dalam live streaming Digital Saving BRI, Nabung Jaman Now berpendapat bahwa kondisi tagline work from home menaikkan transaksi kartu kredit karena pendapatan masyarakat tidak menerima uang lembur dan uang transportasi dari kantor sehingga masyarakat melakukan pembayaran menggunakan kartu kredit dan juga untuk menjaga aliran kas (id.berita.yahoo.com, 2020). Handayani (id.berita.yahoo.com, 2020) menjelaskan bahwa tren penggunaan kartu kredit BRI sendiri meningkat di sektor e-commerce. Masyarakat memanfaatkan kartu kredit untuk mencicil barang yang mereka beli. Pembelian di offline store mengalami stagnan bahkan turun. Di e-commerce meningkat tetapi pola belanjanya berbeda dari sebelumnya.

\section{Data Bank Indonesia}

Sebelumnya, Asosiasi Kartu Kredit Indonesia (AKKI) menyatakan, hingga Maret 2020 transaksi kartu kredit meningkat 7-8 persen. Namun, angkanya menurun dari Maret hingga Juni.

Menurut data Bank Indonesia, volume transaksi kartu kredit tahun 2020 mencapai Rp 349,211 miliar atau tumbuh 3,26 persen dibandingkan tahun 2019 dengan nilai nominal Rp 342,68 triliun atau tumbuh 8,9 persen. Terjadi pertumbuhan, namun masih melambat.

Adapun per 1 Mei 2020 lalu, BRI memberikan relaksasi kepada nasabah Kartu Kredit untuk membantu mereka yang terdampak Covid-19 agar arus kasnya terjaga.

Penyesuaian tersebut antara lain penurunan batas maksimal suku bunga semula 2,25 persen menjadi 2 persen per bulan. Lalu batas minimum pembayaran untuk nasabah yang dibayarkan setiap bulannya turun dari 10 persen menjadi minimal 5 persen per bulan dari total tagihan.

Selain itu, perseroan juga menurunkan besaran denda keterlambatan pembayaran dari 3 persen atau maksimal Rp 150 ribu menjadi 1 persen atau maksimal Rp 100 ribu setiap bulannya. BRI juga memberikan kelonggaran khusus dengan memberikan tenggat waktu perpanjangan pembayaran kartu kredit.

\section{Mulai 1 Juli 2020 Belanja Pakai Kartu Kredit Wajib Gunakan PIN}

Mulai 1 Juli 2020 mendatang, Bank Indonesia (BI) mewajibkan seluruh pemegang Kartu Kredit untuk menggunakan Personal Identification Number (PIN) 6 Digit dan tidak lagi memakai tanda tangan saat bertransaksi untuk autentikasinya.

Hal ini dikarenakan penggunaan PIN untuk transaksi kartu kredit memudahkan dan lebih aman daripada sekadar tanda tangan.

Semua transaksi kartu kredit yang tidak menggunakan autentikasi PIN mulai 1 Juli mendatang akan langsung ditolak oleh mesin Electronic Data Capture (EDC) di merchant, sehingga seluruh pengguna wajib mengaktivasi PIN yang terdiri dari 6 digit angka tersebut.

Perbankan juga telah melakukan persiapan terkait hal ini, misalnya seperti Bank BRI yang menjadi salah satu penerbit kartu kredit (Issuer) maupun Penyelenggara pembayaran (Acquirer) telah melakukan sosialisasi dan edukasi kepada nasabah dan merchant mengenai perubahan tersebut.

\section{METODE PENELITIAN}

Survei Perbankan dilaksanakan secara triwulanan sejak triwulan III-1999. Pengumpulan data periode triwulan III-2020 dilaksanakan pada bulan September 2020. Survei dilakukan untuk memperoleh informasi dini mengenai kebijakan perbankan dalam penyaluran kredit, pendanaan dan penentuan suku bunga, perkembangan permintaan dan penawaran kredit baru. Sampel dipilih secara purposive terhadap +40 bank umum dengan pangsa kredit sekitar $80 \%$ dari total kredit. Pengolahan data dilakukan dengan menggunakan metode "Saldo Bersih Tertimbang" (SBT), yakni jawaban responden dikalikan dengan bobot kreditnya (total 100\%), selanjutnya dihitung selisih antara persentase responden yang memberikan jawaban meningkat dan menurun. Indeks Lending Standar (ILS) menggunakan Saldo Bersih Tertimbang berdasarkan bobot kredit responden terhadap total kredit 
responden dan bobot jawaban (Lebih Ketat (1), Sedikit Lebih Ketat (0,5), Tidak Berubah (0), Sedikit Lebih Longgar (-0,5), Lebih Longgar (-1). Nilai SBT > 0 berarti lebih ketat, dan SBT < 0 berarti lebih longgar.

\section{HASIL DAN PEMBAHASAN}

Kartu Kredit adalah cara pembayaran yang memberikan anda kemudahan dalam melakukan pembayaran transaksi keuangan anda. Namun demikian, anda harus memperhatikan biaya dan risiko yang mungkin timbul dalam penggunaannya.

\section{Pantaulah pengeluaran anda}

Kartu kredit adalah alat pembayaran yang dapat memberikan kemudahan bagi anda dalam melakukan transaksi namun demikian anda tetap harus berhati-hati dalam menggunakannya. Anda dapat saja dengan mudah terjebak dalam utang kartu kredit yang sulit untuk anda lunasi sehingga berpotensi untuk memberikan anda kesulitan di kemudian hari. Jadi, kendalikan pengeluaran anda sesuai dengan kemampuan pembayaran anda dan selalu melakukan pengecekan terhadap tagihan kartu kredit bulanan anda.

\section{Bayarlah Kartu Kredit Anda Tepat Waktu}

Ketika anda memperoleh tagihan kartu kredit, periksalah tanggal jatuh tempo dan pastikan anda membayar secara tepat waktu. Hal ini akan menghindarkan anda dari biaya keterlambatan (late charge fee) dan bunga.

\section{Maksimalkan Pembayaran Anda}

Apabila anda hanya melakukan pembayaran minimum setiap bulannya, maka anda akan membayar mahal untuk bunga dan akan membutuhkan waktu yang lama untuk melunasi tagihan anda.

Sebaiknya anda membuat rencana pembayaran kartu kredit melebihi jumlah minimum pembayaran sehingga dapat segera melunasi utang kartu kredit anda.

\section{Tentukan batas pagu kartu kredit yang sesuai dengan kemampuan anda}

Mintalah limit kartu kredit yang sesuai dengan kemampuan anda untuk membayar. Jangan tergoda untuk menggunakan seluruh limit kartu kredit anda dan menggunakan kartu kredit melebihi kemampuan anda.

Limit kartu kredit anda bukanlah untuk anda habiskan. Anda harus memastikan bahwa limit kartu kredit anda berada dalam batas kemampuan anda. Jangan tergoda untuk menghabiskan limit kartu kredit anda untuk berbelanja.

Apabila anda ingin mengurangi limit kartu kredit anda, anda dapat menghubungi penerbit kartu kredit anda.

Harus diketahui bahwa Penerbit tidak bisa menaikkan limit kartu kredit anda tanpa persetujuan pemegang kartu kredit. Apabila anda ingin menaikkan limit kartu kredit anda untuk keperluan tertentu (misalnya bepergian ke luar negeri), ingatlah untuk segera menurunkan kembali limit kartu anda sesuai dengan kebutuhan.

\section{Jangan menggunakan kartu kredit untuk memenuhi kebutuhan anda}

Apabila anda memiliki kebutuhan darurat atau kekurangan uang tunai, penggunaan kartu kredit atau cash advance tidak disarankan untuk jangka waktu panjang. Kartu kredit mungkin dapat menyelamatkan anda saat ini, namun apabila anda tidak segera menyelesaikannya maka akan menimbulkan masalah baru bagi anda. Sebaiknya anda memiliki tabungan untuk menyelesaikan keperluan darurat sehingga tidak bergantung pada penggunaan kartu kredit. Jangan melakukan 
transaksi gesek tunai (gestun) karena kegiatan tersebut dilarang oleh Bank Indonesia dan berpotensi untuk merugikan konsumen dalam jangka panjang.

\section{Periksalah selalu tagihan kartu kredit anda}

Cara yang terbaik untuk memeriksa tagihan kartu kredit anda adalah dengan menyimpan seluruh slip transaksi kartu kredit anda dan membandingkan slip dimaksud dengan tagihan kartu kredit anda. Hal ini untuk memastikan bahwa anda ditagih untuk transaksi yang memang anda lakukan.

Apabila terdapat transaksi yang tidak anda lakukan, segera hubungi Penerbit kartu kredit anda untuk mengkonfirmasi kembali tagihan dimaksud.

\section{Tutup kartu kredit anda secara benar}

Apabila anda ingin menutup kartu kredit anda, maka anda harus meyakini bahwa proses penutupan kartu kredit dilakukan oleh pihak yang berwenang dan tidak terdapat tagihan yang tertinggal atau belum terselesaikan. Sebaiknya permintaan penutupan kartu kredit anda juga dilakukan dalam bentuk tertulis untuk meyakini.

\section{Daftar Bank Penerbit Kartu Kredit}

\begin{tabular}{|r|l|r|l|} 
No. & \multicolumn{1}{|c|}{ Nama Penerbit } & No. & \multicolumn{1}{|c|}{ Nama Penerbit } \\
\hline 1 & PT. BANK BUKOPIN, Tbk & 14 & PT. BANK OCBC NISP, Tbk \\
\hline 2 & PT. BANK CENTRAL ASIA, Tbk & 15 & PT. BANK PERMATA, Tbk \\
\hline 3 & PT. BANK CIMB NIAGA, Tbk & 16 & PT. BANK QNB INDONESIA, Tbk \\
\hline 4 & PT. BANK DANAMON INDONESIA, Tbk & 17 & PT. BANK RAKYAT INDONESIA \\
\hline 5 & PT. BANK DBS INDONESIA & 18 & PT. BANK SINARMAS, Tbk \\
\hline 6 & PT. BANK HSBC INDONESIA & 19 & PT. BANK UOB INDONESIA \\
\hline 7 & PT. BANK ICBC INDONESIA & 20 & PT. BANK BNI SYARIAH \\
\hline 8 & PT. BANK MANDIRI (PERSERO), Tbk & 21 & CITIBANK, N.A. \\
\hline 9 & PT. BANK MAYAPADA INTERNATIONAL, & 22 & PT. PANIN INDONESIA BANK, Tbk \\
\hline 10 & PT. BANK MAYBANK INDONESIA, Tbk & 23 & STANDARD CHARTERED BANK \\
\hline 11 & PT. BANK MEGA, Tbk & 24 & PT. AEON CREDIT SERVICES \\
\hline 12 & PT. BANK MNC INTERNASIONAL, Tbk & 25 & PT. HOME CREDIT INDONESIA \\
\hline 13 & PT. BANK NEGARA INDONESIA & 26 & PT. SHINHAN INDO FINANCE \\
\hline
\end{tabular}




\section{Perkembangan Kartu Kredit Selama Pandemi Covid-19}

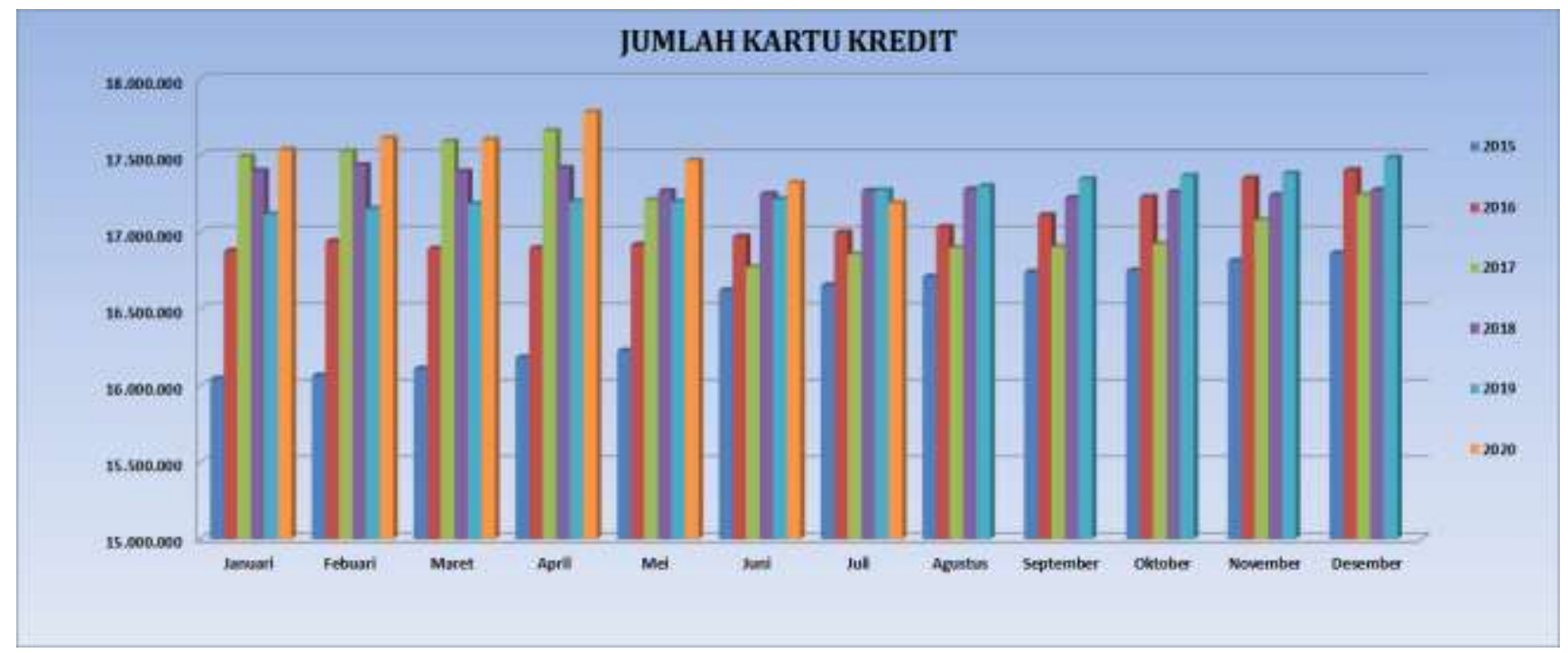

\section{Grafik 1 Jumlah Kartu Kredit (Sumber : www.akki.or.id)}

Grafik 1 menjelaskan bahwa jumlah Kartu Kredit tahun 2020 (Kurva warna orange) meningkat paling tinggi di bulan April di saat Pandemi Covid'19 yang mulai melakukan pembatasan sosial berskala besar (PSBB) disaat itu. Jumlah kartu kredit lebih besar dari 17,5 juta namun kurang dari 18 juta $(17.500 .000<$ kartu kredit April $2020<18.000 .000)$.

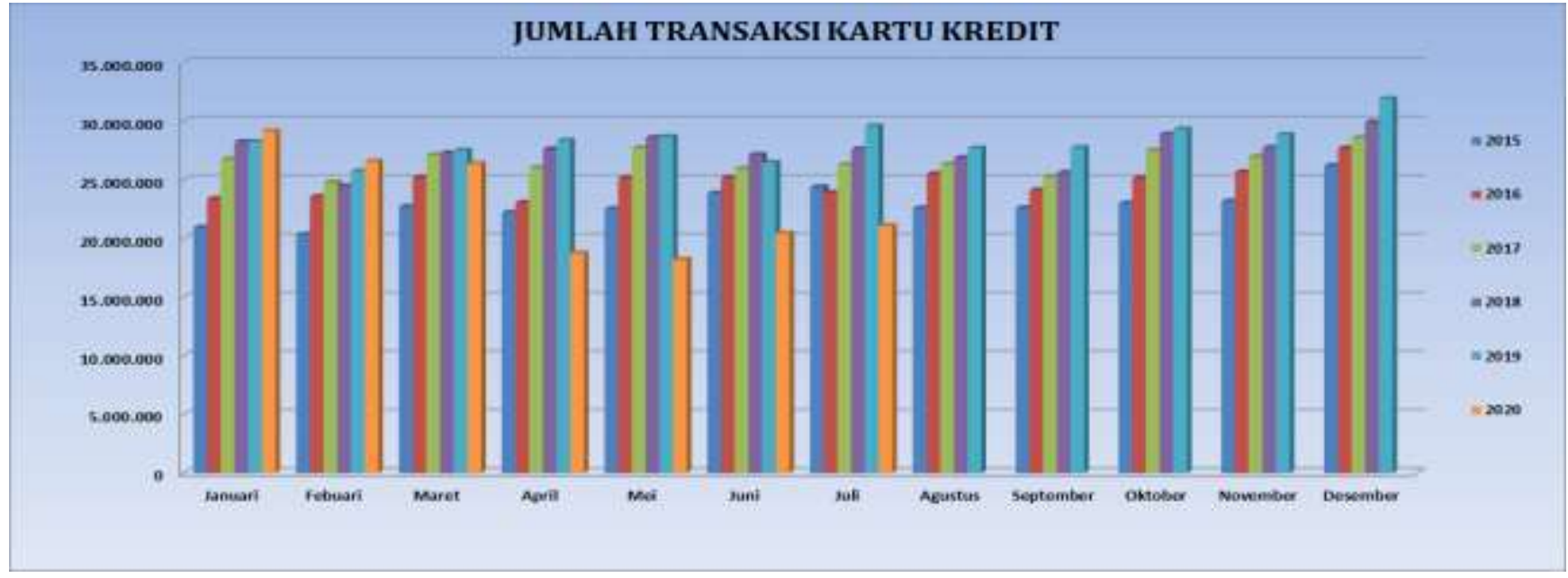

\section{Grafik 2 Transaksi Kartu Kredit \\ (Sumber : www.akki.or.id)}

Grafik 2 menjelaskan bahwa jumlah pertumbuhan transaksi kartu kredit pada tahun 2020 di masa pandemi covid'19 mulai dari bulan April dan Mei dapat menurun dari transaksi pada bulan sebelumnya. Jumlah transaksi kartu kredit bulan April dan Mei kurang dari 20 juta transaksi, sedangkan transaksi kartu kredit tertinggi ada pada bulan Januari 2020 saat Covid-19 muncul ke dunia dan mulai menyebar ke Indonesia sejumlah kurang dari 30 juta transaksi $(25.000 .000<$ Transaksi kartu kredit tertinggi $<30.000 .000)$. 


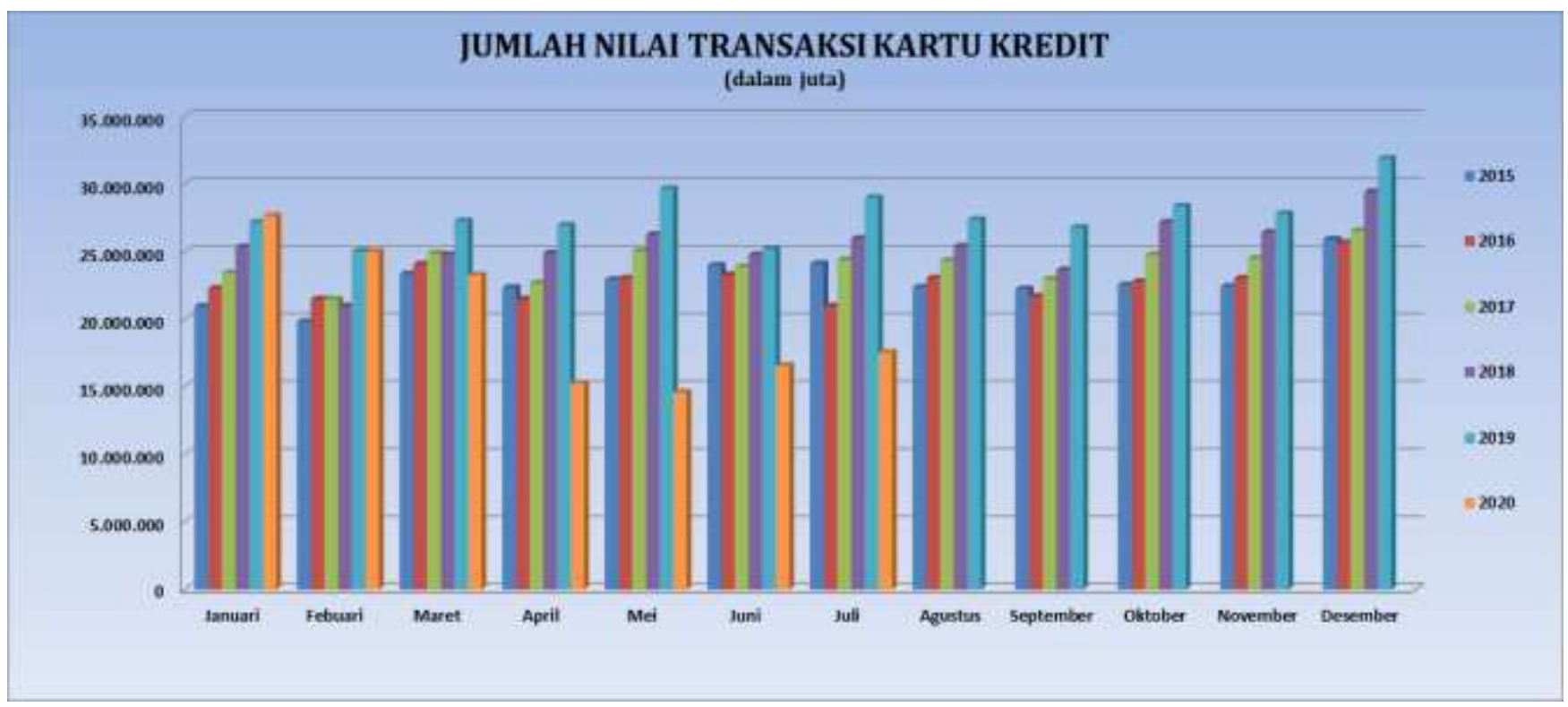

\section{Grafik 3 Nilai Transaksi Kartu Kredit 2015-2020 \\ (Sumber : www.akki.or.id)}

Grafik 3 menjelaskan bahwa jumlah nilai transaksi kartu kredit dapat kita lihat di bulan April dan Mei 2020 sangat turun dimana awal PSBB di Jakarta. Jumlah nilai transaksi kartu kredit bulan April-Mei kurang dari 15.000.000.

\section{PENUTUP}

Transaksi kartu kredit sejumlah bank mengalami peningkatan cukup signifikan sejak Juni hingga Agustus 2020 dibanding dengan kondisi selama masa pembatasan sosial berskala besar (PSBB). Namun, transaksi sepanjang tahun ini masih tetap menurun jika dibanding periode yang sama tahun lalu. Bank melihat sulit untuk mengejar pertumbuhan kartu kredit tahun ini, namun sejumlah strategi tetapi disiapkan untuk mendorong transaksi paling tidak bisa sama dengan tahun 2019.

\section{REFERENSI}

Budisantosa \& Nuritomo. (2017). Bank Dan Lembaga Keuangan Lain. Jakarta: Salemba Empat https://id.wikipedia.org/wiki/Kartu_kredit (16 November 2020, pukul 02.31)

\section{https://www.akki.or.id/index.php/mnuprofile}

https://www.bi.go.id/id/Default.aspx

https://id.berita.yahoo.com/transaksi-kartu-kredit-malah-meningkat-092020382.html(rabu, 29/07/2020)

\section{https://sikapiuangmu.ojk.go.id/FrontEnd/CMS/Article/340}

WWW.ojk.go.id 